\title{
ANDROGEN-BINDING PROTEIN IN EFFERENT DUCT FLUID OF RAT TESTIS
}

\author{
F. S. FRENGH* AND E. M. RITZÉN \\ Pediatric Endocrinology Unit, Department of Pediatrics, and \\ Swedish Medical Research Council Reproductive Endocrinology Research Unit, \\ Karolinska sjukhuset, S-104 01 Stockholm 60, Sweden
}

(Received 2nd May 1972)

Testicular fluid obtained from the rete testis and vasa efferentia has been reported to contain testosterone in concentrations approaching the amount in spermatic venous blood (Voglmayr, Waites \& Setchell, 1966; White \& Hudson, 1968). Flow rates, which have been established in several mammalian species (Setchell, 1970; Tuck, Setchell, Waites \& Young, 1970) would indicate that the exocrine secretion may deliver a substantial quantity of androgen to the caput epididymidis. Testosterone and possibly other androgens in rete testis fluid might also exert a direct influence on spermatozoa as they are transported in this fluid.

In the present report, a specific androgen-binding protein with high affinity for dihydrotestosterone (DHT) and testosterone ( $\mathrm{T}$ ) is demonstrated in rete testis and efferent duct fluid from the rat testis. Fluid was collected after ligation of the vasa efferentia for 18 to $20 \mathrm{hr}$ or for 3 days. The 18- to 20-hr ligations were made as close to the capsule of the testis as possible and rete testis fluid was collected from anaesthetized rats as described by Setchell \& Waites (1971). The 3-day ligations were placed mid-way between testis and caput epididymidis. Animals were decapitated and the efferent ducts were dissected free of blood vessels before collection of fluid by opening the distended ducts. Spermatozoa were removed by centrifugation and the fluid was stored at $-20^{\circ} \mathrm{C}$. Both methods yielded 0.2 to $0.4 \mathrm{ml}$ fluid/testis. Total protein concentrations were measured by the method of Lowry, Rosebrough, Farr \& Randall (1951), using a bovine serum albumin standard. Values of the means and individual standard deviations were $2.4 \pm 0.6 \mathrm{mg} / \mathrm{ml}$ in several samples of rete testis fluid collected 18 to $20 \mathrm{hr}$ after ligation and $8.4 \pm 0.4 \mathrm{mg} / \mathrm{ml}$ in efferent duct fluid collected 3 days after ligation.

Testicular fluid was diluted in $0.01 \mathrm{~m}$-tris-HCl buffer, $\mathrm{pH} 7.5$, containing 0.0015 м-EDTA, $0.002 \mathrm{M}$-2-mercaptoethanol, $10 \%$ glycerol and $0.5 \%$ bovine albumin (TEMGA-buffer). Aliquots of diluted fluid were equilibrated at $0^{\circ} \mathrm{C}$ for $2 \mathrm{hr}$ with tritium-labelled steroids. Proteins were fractionated by polyacrylamide gel electrophoresis (PAGE) and the radioactivity measured in 2-4-mm slices as described by Ritzén, Nayfeh, French \& Dobbins (1971). Text-figure 1 shows the single peak of bound $\left[1,2-{ }^{3} \mathrm{H}\right]$ dihydrotestosterone

\footnotetext{
* Present address: Department of Pediatrics and the Laboratories for Reproductive Biology, University of North Carolina, Chapel Hill, N.G. 27514, U.S.A.
} 
$\left(\left[{ }^{3} \mathrm{H}\right] \mathrm{DHT}\right)$ obtained when $0 \cdot 15 \mathrm{ml}$ fluid freshly collected from a single testis was diluted to $0.45 \mathrm{ml}$ with TEMGA buffer and equilibrated with $0.1 \mu \mathrm{Ci}$ $(0.66 \mathrm{ng})\left[{ }^{3} \mathrm{H}\right] \mathrm{DHT}$ for $2 \mathrm{hr}$ at $0^{\circ} \mathrm{C}$. A similar aliquot of fluid was diluted in TEMG buffer (albumin omitted) and run in parallel for protein staining with amido black. Samples were layered directly over $6.5 \%$ gels and run at $0^{\circ} \mathrm{C}$ in tris-glycine buffer ( $\mathrm{pH} \mathrm{8.9),} 5 \mathrm{~mA} /$ tube for $3 \mathrm{hr}$.

No qualitative difference was noted in the peaks of bound radioactivity or patterns of protein bands obtained from fluids collected 18 to $20 \mathrm{hr}$ and 3 days after efferent duct ligation. Albumin did not bind DHT and T in this PAGE system but stabilized the specific androgen-binding protein. Extraction of efferent duct fluid with charcoal ( $1 \mathrm{mg} / \mathrm{mg}$ protein) at $0^{\circ} \mathrm{G}$ for $12 \mathrm{hr}$ was shown to increase the binding of trace amounts of $\left[1,2-{ }^{3} \mathrm{H}\right] \mathrm{T}$, suggesting the extraction of endogenously bound androgen.

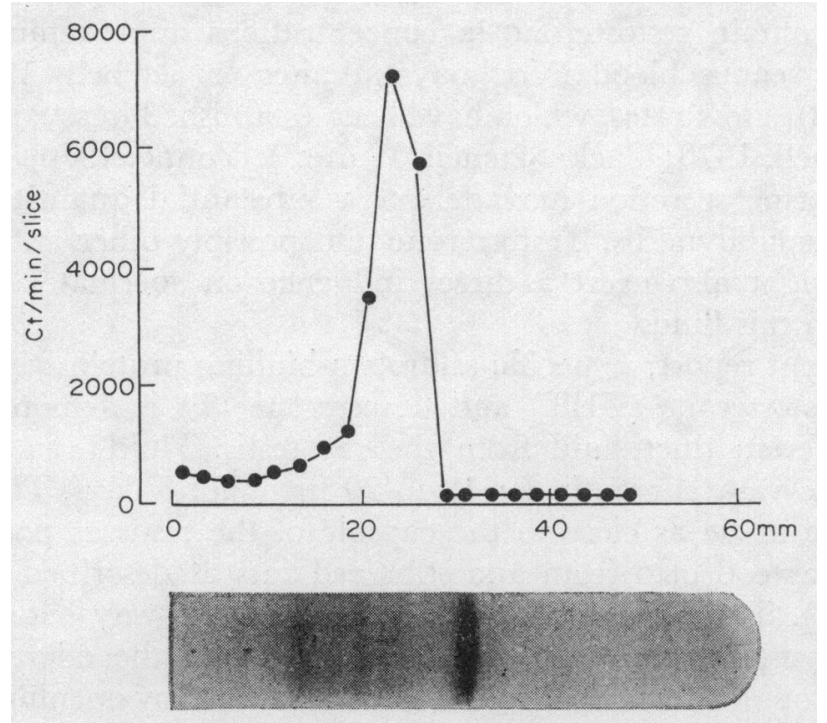

Text-Fig, 1. Binding of $\left[1,2-{ }^{3} \mathrm{H}\right]$ dihydrotestosterone $\left(\left[{ }^{3} \mathrm{H}\right] \mathrm{DHT}\right)$ in efferent duct fluid from rat testis fractionated by polyacrylamide gel electrophoresis.

The electrophoretic mobility of the binding component in testicular fluid was identical to that of the androgen-binding component previously described in a 105,000 $\mathrm{g}$ supernatant of rat epididymis homogenate (Ritzén et al., 1971). In both efferent duct fluid and epididymis supernatant, binding activity was destroyed by prior treatment with the proteolytic enzyme Protease Type VII (Sigma). Detailed comparisons of the physico-chemical properties of the highaffinity androgen-binding protein (ABP) in rat testis and epididymis indicate they are identical to the ABP in rete testis and efferent duct fluids (Ritzén, Dobbins, French \& Nayfeh, 1972).

A quantitative estimation of binding sites was made (Text-fig. 2), utilizing the Sephadex gel equilibration assay of Pearlman \& Crèpy (1967) modified as previously described by Ritzén et al. (1971). Rete testis fluid $(2.0 \mathrm{ml})$, collected from four rats 18 to $20 \mathrm{hr}$ after efferent duct ligation, was diluted 
$1: 3$ in TEMGA buffer (containing $0.5 \%$ human albumin) and extracted with charcoal $\left(1 \mathrm{mg} / \mathrm{mg}\right.$ albumin) at $0^{\circ} \mathrm{C}$ for $12 \mathrm{hr}$. Charcoal was removed by centrifugation repeated several times. Sephadex G-25 (200 mg) was placed in glass-stoppered tubes with $1 \mathrm{ml} \mathrm{TEMG} \mathrm{buffer} \mathrm{(albumin} \mathrm{omitted)} \mathrm{and} \mathrm{allowed}$ to swell overnight at $25^{\circ} \mathrm{C}$. To each assay tube was added $0.25 \mathrm{ml}$ diluted rete testis fluid, $0.25 \mathrm{ml}$ TEMG-buffer containing $\left[{ }^{3} \mathrm{H}\right] \mathrm{DHT}(0.04 \mu \mathrm{Ci}$, $0.25 \mathrm{ng}$ ), and $0.50 \mathrm{ml}$ TEMG buffer containing $0,1,3,6$ or $12 \mathrm{ng}$ DHT. Tubes were shaken horizontally for $1 \mathrm{hr}$ at $0^{\circ} \mathrm{C}$ and placed upright for $1 \mathrm{hr}$.

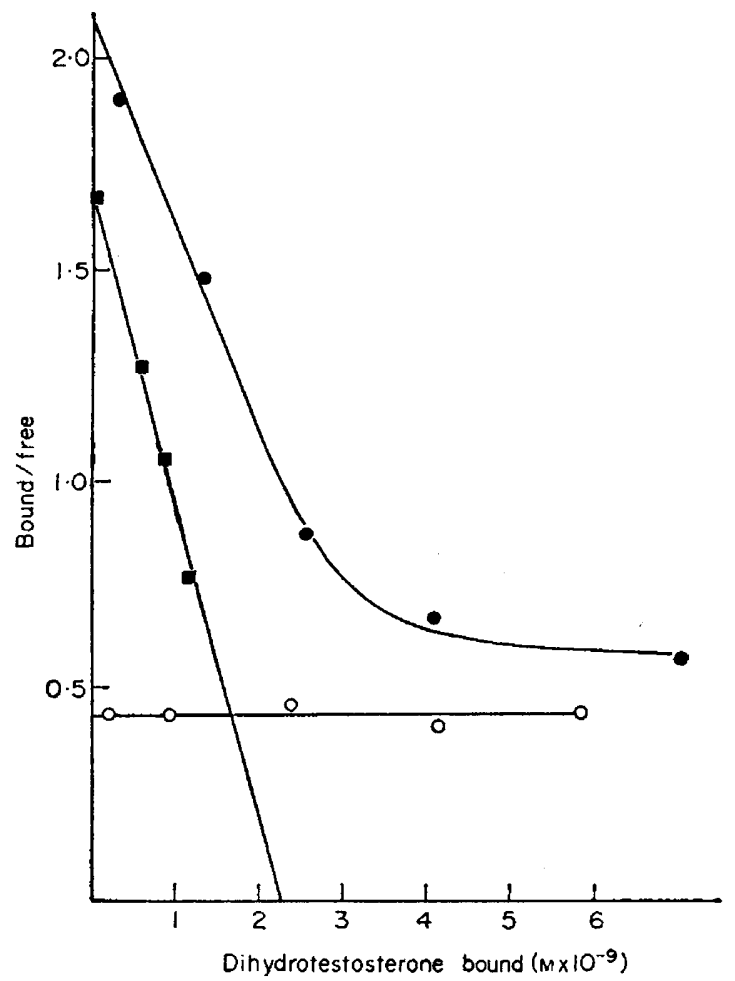

TEXT-FIG. 2. Scatchard plot of DHT-binding in rete testis fluid collected 18 to $20 \mathrm{hr}$ after efferent duct ligation. $\bullet$, Rete testis fluid +albumin; $O$, albumin; $\square$, rete testis fluid.

Radioactivity was counted in aliquots of the clear supernatants. Total bound steroid was plotted on the abscissa and the ratio of bound/free on the ordinate. Charcoal-extracted TEMGA-buffer was assayed separately and the corrected Scatchard plot of DHT-binding to the high-affinity sites was obtained graphically as described by Sandberg, Rosenthal, Schneider \& Slaunwhite (1966). The concentration of ABP-binding sites in this rete testis fluid, $4 \cdot 2 \times$ $10^{-8} \mathrm{M}$, was calculated from the $\mathrm{x}$-axis intercept of the corrected Scatchard plot.

Binding affinities and concentrations of ABP-binding sites for DHT and $T$ in charcoal-extracted efferent duct fluid were compared by PAGE and by Sephadex gel equilibration (Text-fig. 3). For PAGE, the fluid was diluted 
$1: 4.5$ in TEMGA buffer (containing $0.5 \%$ bovine serum albumin) and extracted with charcoal as in Text-fig. 1 . Aliquots of $0.5 \mathrm{ml}$ were equilibrated with $0.8 \mu \mathrm{Ci}(5.28 \mathrm{ng})\left[{ }^{3} \mathrm{H}\right] \mathrm{DHT}$ or $\left[{ }^{3} \mathrm{H}\right] \mathrm{T}$ and $10.72 \mathrm{ng} \mathrm{DHT}$ or $\mathrm{T}$, amounts of the androgens which would completely saturate the binding sites, before fractionation (Text-fig. 3a). For Sephadex gel equilibration, the fluid was diluted $1: 7$ in TEMGA buffer (containing $0.5 \%$ bovine serum albumin). To each assay tube was added $0.25 \mathrm{ml}$ efferent duct fluid, $\left[{ }^{3} \mathrm{H}\right] \mathrm{DHT}$ or $\left[{ }^{3} \mathrm{H}\right] \mathrm{T}$ $(0.04 \mu \mathrm{Ci}, 0.25 \mathrm{ng})$ in $0.25 \mathrm{ml}$ TEMG buffer and $0.50 \mathrm{ml}$ TEMG buffer containing $0,1,3$ or $6 \mathrm{ng}$ of DHT or T. Charcoal-extracted TEMGA buffer was assayed separately and the individual values subtracted to obtain corrected values for the specific androgen-binding protein (Text-fig. $3 \mathrm{~b}$ ).

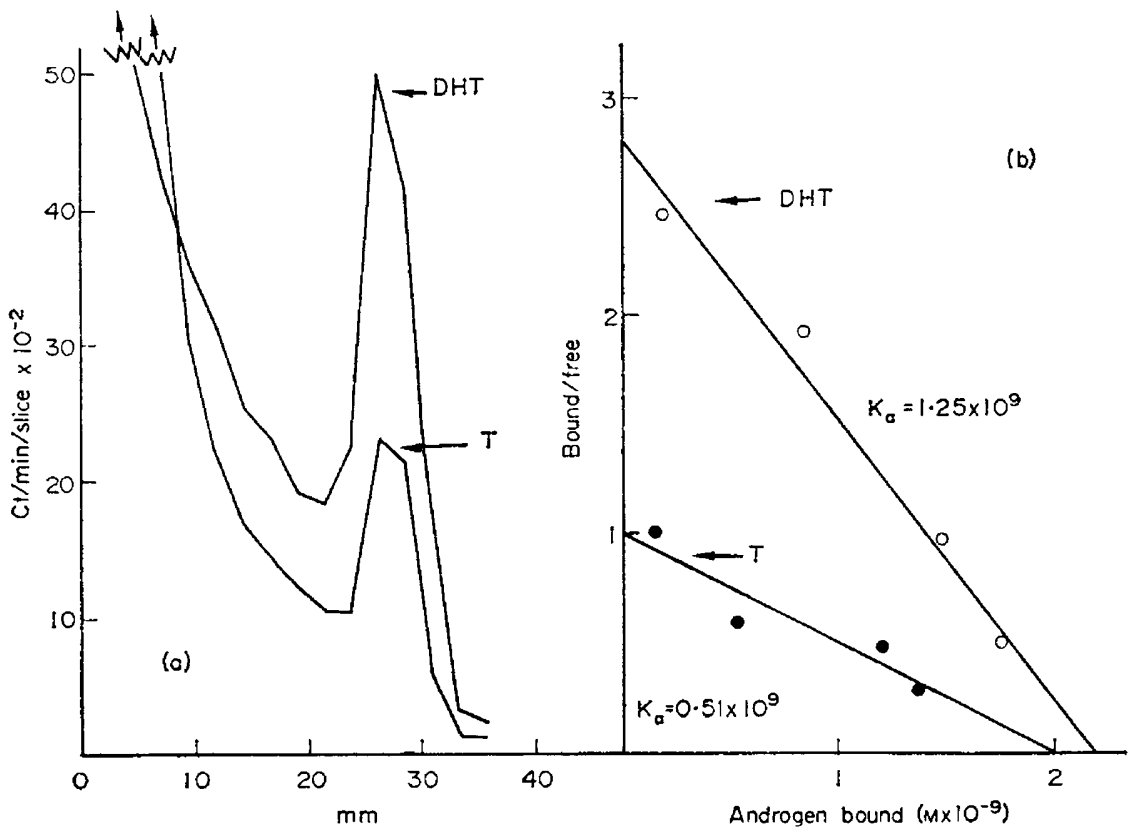

TexT-FIG. 3. (a) Relative binding of $\left[{ }^{3} \mathrm{H}\right] \mathrm{DHT}$ and $\left[{ }^{3} \mathrm{H}\right] \mathrm{T}$ in efferent duct fluid collected 3 days after ligation. (b) Scatchard plots of DHT- and T-binding in efferent duct fluid collected as above and measured by Sephadex gel equilibration as in Text-fig. 2. Regression lines were computed by the method of least squares and extrapolated to the $\mathbf{x}$ and $y$ axes to obtain intercept values of $n$ (the concentration of binding sites) and $n K$. $\left(K_{\mathrm{a}}=\right.$ equilibrium constant of association).

The relative amounts of DHT (2.44 $\mathrm{ng})$ and $\mathrm{T}(1.06 \mathrm{ng})$ remaining bound after PAGE fractionation (Text-fig. 3a) closely resembled relative values of the equilibrium constants of association $\left(K_{\mathrm{a}}\right)$ for DHT and T as determined by Sephadex gel equilibration (Text-fig. $3 \mathrm{~b}$ ). The $K_{\mathrm{a}}$ for DHT was 2.5 times greater than the $K_{\mathrm{a}}$ for $\mathrm{T}$. The similar concentrations of binding sites (Textfig. $3 \mathrm{~b}$ ) and identical electrophoretic mobilities strongly suggested that DHT and $\mathrm{T}$ bind to the same site. Further evidence for a common site was obtained previously when it was demonstrated by competitive binding assay that $\left[{ }^{3} \mathrm{H}\right]$ DHT bound to ABP sites in epididymis supernatant could be displaced by $\mathrm{T}$ (Ritzén et al., 1971). A high degree of specificity for $\mathrm{T}$ and DHT was exhibited 
by the $A B P$ in this PAGE system. There was a relatively small affinity for $\left[1,2-{ }^{3} \mathrm{H}\right] 5 \alpha$-androstane- $3 \alpha, 17 \beta$-diol, but no binding of $\left[1,2-{ }^{3} \mathrm{H}\right]$ androstenedione, $\left[1,2-{ }^{3} \mathrm{H}\right]$ progesterone, or $\left[2,4,6,7-{ }^{3} \mathrm{H}\right]$ oestradiol was noted.

The concentration of androgen-binding sites in fluid collected 3 days after efferent duct ligation was $8.5 \times 10^{-8} \mathrm{M}$ which reflects the larger quantity of total protein in this fluid. The position of the ligature in these preparations probably permitted fluid to be absorbed in the efferent ducts, and the concentration of protein may indicate a preferential absorption of water in this region of the ducts. Resorption of fluid was also demonstrated by formation of sperm plugs in the ligated efferent ducts.

In studies reported elsewhere (French \& Ritzén, 1972), it was demonstrated that the $\mathrm{ABP}$ is formed in the testis and may serve as a carrier of androgen from testis to epididymis. During its passage through the caput epididymidis, a major portion of the ABP either loses its binding activity or disappears from the soluble supernatant because of absorption from the lumen and uptake by an insoluble subcellular organelle of epididymal cells.

This work was supported by the Swedish Medical Research Council Grant 13X-3168, USPHS Grant HDO4466 and the Swedish Medical Research Council Visiting Scientist Programme. One of us (F.S.F.) was the recipient of a Kenan Research Leave from the University of North Carolina.

The authors are indebted to Dr B. P. Setchell for demonstrating the collection of rete testis fluid, and for helpful discussions. Mr Lars Uno Larsson, Miss Elisabet Lindberg and Miss Gunilla Persson provided skilful technical assistance.

\section{REFERENCES}

FreNGH, F. S. \& Rrtzén, E. M. (1972) High affinity androgen binding protein in rat testis: evidence for secretion in efferent duct fluid and absorption by epididymis. Endocrinology (in press).

Lowry, O. H., Rosebrovgh, N. J., FarR, A. L. \& Randall, R. J. (1951) Protein measurement with the folin phenol reagent. $\mathcal{F}$. biol. Chem. 193, 265.

Pearlman, W. H. \& GRÈPY, O. (1967) Steroid-protein interaction with particular reference to testosterone binding by human serum. F. biol. Chem. 242, 182.

Rrtzén, E. M., Dobsins, M. G., French, F. S. \& NAYFeH, S. N. (1972) Characterization of an androgen binding protein (ABP) in rat testis and epididymis. Steroids (in press).

Rrtzén, E. M., NAypeh, S. N., French, F. S. \& Dobbins, G. (1971) Demonstration of androgen binding components in rat epididymis cytosol and comparison with binding components in prostate and other tissues. Endocrinology, 89, 143.

Sandeerg, A. A., Rosenthal, H., Schneider, S. L. \& Slaunwhite, W. R. (1966) Protein-steroid interactions and their role in the transport and metabolism of steroids. In: Steroid Dynamics, p. 1. Eds. G. Pincus, T. Nakao and J. F. Tait. Academic Press, New York and London.

Setchell, B. P. (1970) Testicular blood supply, lymphatic drainage and secretion of fuid. In: The Testis, Vol. I, p. 101. Eds. A. D. Johnson, W. R. Gomes and N. L. VanDemark. Academic Press, New York and London.

Setchell, B. P. \& WaItes, G. M. H. (1971) The exocrine secretion of the testis and spermatogenesis. 7. Reprod. Fert. Supp1. 13, 15.

Tuck, R. R., Setchell, B. P., Waites, G. M. H. \& Young, J. A. (1970) The composition of fluid collected by micropuncture and catheterization from the seminiferous tubules and rete testis of rats. Pfiugers Arch. ges. Physiol. 318, 225.

Voglmayr, J. K., Waites, G. M. H. \& Setchell, B. P. (1966) Studies on spermatozoa and fluid collected directly from the testis of the conscious ram. Nature, Lond. 210, 861.

White, I. G. \& Hudson, B. (1968) The testosterone and dehydroepiandrosterone concentrations in fluids of the mammalian reproductive tract. F. Endocr. 41, 291. 